\title{
Institutional Rural Land Dispute Management Strategies: Lessons from Buhera District, Zimbabwe
}

\author{
Guta Gerald ${ }^{1}$, Chinyama Roseline ${ }^{2}$ \\ ${ }^{1}$ Lecturer, Department of Rural and Urban Development, ${ }^{2}$ Rural Development Graduate \\ Great Zimbabwe University, Masvingo, Zimbabwe
}

\begin{abstract}
The research sought to assess the effectiveness of institutional rural land dispute management strategies. The research was carried in the form of a case study, in which a sample of 40 participants from a population of 123 was used. Purposive and simple random sampling procedures were employed in selecting elements from a population of 123 . Questionnaires and interviews were used in triangulation to collect data on the sample. After analyzing the collected data, the researcher observed that non -consensual strategies are effective in resolving rural land disputes in Zimbabwe. The research also revealed that Traditional leaders are key actors in rural land dispute resolution. The study recommended that all conflicting parties be involved in resolving rural land disputes.
\end{abstract}

Keywords: conflict resolution, institutional land disputes, management

\section{INTRODUCTION:}

Conflicts cannot be evaded in human interactions as social, religious, economic and political issues are seen to be at the core of the basis of human disputes. As such, differences in interest on these issues can cause conflict of various natures. Conflict resolution strategies must be used as they go a long way in managing and discarding conflicts from escalation. Wallensteen, (2007) defines conflict resolution as actions by conflicting parties to willingly solve their discrepancies. Conflict resolution comprises numerous methods and procedures intended to redact or manage conflict (Wallensteen,2007).Kriesberg (1997) states that conflict resolution strategies evolves through phases and for each and every phase researchers devised resolution strategies. Thomas and Kilman (1976) devise a five basic method approach of addressing conflicts that include accommodation, avoidance, collaboration, compromise and competition. Glasl (1999) also recommended third party involvement in conflict resolution which give birth to arbitration, facilitation, mediation, conciliation, consultation, moderation, socio therapeutic and adjudication. Wehrmann (2008) reduced the strategies into consensual and nonconsensual approaches. It is important to note that conflict resolution strategies can be used in different disciplines namely non-governmental organisations, traditional organisations, multi-agent systems and land disputes (Kuzhanga 2013, Rukuni et, al.2015, Jung, 2003, Twasi 2016, Boudreaux et al 2017).

Globally, the list of how land dispute cases have been managed is long. In Sharia, mediation has been habitually the endorsed first-order mechanism to dispute resolution after compromise failed to work (Sait and Lim 2006). Mediation present a constructive platform for solving micro-level land conflicts and is regularly referred to when dealing with communitybased land dispute resolution (World Bank 2005). The Western Sahara territory offers another case of land disputes at global level. The dispute has been between the indigenous people and their colonial rulers (Dahlitz, 2003). The conflict lasted for 35 years and it becomes an extreme example of a long lasting failed land dispute. In spite of being an efficient mediator in this dispute, the United Nations as a third party, failed to resolve the conflict over the period and this conflict is still to be resolved.

Land disputes in Africa can be traced back as the early 1900s and 1960s (Ngombe, et al, 2006). Different strategies to conflict resolution have been used in Africa. Namibia reinstituted a land tribunal and land policies as an effective technique for dealing 
with land disputes. The land tribunal was very efficient and managed to resolve about 2345 land dispute cases (Moore, 2010).Zimbabwe also used different strategies to manage land disputes. Zimbabwean government used agreements signed between them and the white settlers as a virtuous method to solve land conflicts. Buhera district was not spared from land disputes. Buhera district ward 14 has been held under two tenure system statutory land designed for Murambinda growth point which is administered by rural local authority and traditional authorities grounded on customary law. Presently the land that has been apportioned for the growth point has been used up. Efforts by the local planning authority to acquire land in the communal area of Chief Nyashanu and Chief Makumbe have since resulted in serious land disputes as the traditional leaders and community residents are not willing to give up land.

\section{Literature Review}

Conflict resolution strategies can be used to deal with conflicts at different levels. Resolution is an act of achieving a positive result to a conflict. CRS hence is a method anticipated to develop peaceful means of harmoniously ending a state of conflict (Burton, 1990). The concept of CRS should therefore be regarded as a state whereby the parties in conflict are equally content with the result of a settlement and the conflict is resolved in a true sense of it. Sweeney and Carruthers (1996) define conflict resolution as the practise used by parties in conflict to reach a settlement. Thus generally conflict resolution refers to the process of managing or handling a conflict situation successfully. Kriesberg (1997) provides a synopsis of the field of conflict resolution. Kriesberg (1997) notes that as a definite field of study, conflict resolution begin in 1950s and has developed in four different phases.

Kriesberg recognises 1950 as a precursor age. During Cold War period the launch of nuclear weapons along the disputes concerning superpowers appeared to intimidate human existence. This saw a number of inventors from diverse field arising in respond to disputes and realized the significance of studying conflict resolution as a universal phenomenon. They recognised the importance of relating tactics that were developing in industrial associations and community mediation situations to conflicts in general, as well as civil and global conflicts. A number of academia in
Europe and North America began to launch researches to advance these new ideas.

The period from 1960 to 1969 saw a swift escalation of conflict resolution studies as new ideas of managing conflicts begun to attract nations and the field began to develop and spread. This saw the establishment of institutions to study conflict resolution. The field established different sectors for specific area for instance groups studying social conflicts, international crisis and methods ranging from negotiation and mediation to experimental games.

The period 1970 to 1985 had seen conflict resolution practically flourishing and agreement was held on many of the fundamental ideas of the field. Researchers agreed on the significance of reframing disputes as shared problems with reciprocal acceptable solutions, on the usefulness of intermediaries in solving conflict as well as the value of training mediators and negotiators. Feminist approaches and the concept of social movement added important new insights to the field.

In this present period, the field has stretched its attention to embrace post-settlement reconciliation and conflict prevention. The nature of universal disputes has changed in the contemporary period. Academics have shifted their focus with concern to understand the current world dynamics. Numerous authors have suggested different methods of resolving conflicts. Dzurgba (2006) notes that once conflicts are settled through dialogue then peace will prevail. Umstot (1987) itemized four approaches that might be used to manage or resolve conflicts. According to Umstot (1987) the conflict resolution approaches include, avoiding, accommodating, compromising, and collaborating. He further argues that, when choosing a CRS, the first decision is whether to confront or avoid the conflict. The degree and nature of the dispute determines CRS to be used. Galsl (1999) recommended use of eight strategies that requires involvement of a third party in conflict resolution if the conflict is volatile. Wehrmann (2008) divided the eight conflict resolution strategies into two comprehensive categories which include consensual and non-consensual. However in this research eight resolution strategies recommended by Glasl (1999) shall be used. 


\section{Conflict Resolution Strategies Consensual approaches}

Rukini (2015) states that consensual approaches seeks to attain a solution that will be tolerable to all conflicting parties. In addition Bernard (2002) argues that consensual approaches fosters negotiations and discussions and this allows conflicting parties to understand other parties' interests, feelings, motivation and eventually their desires and fears. He further states that consensual approaches include consultation, socio-therapeutically consultation, moderation, facilitation conciliation and mediation.

\section{Facilitation}

Best (2006) posits that facilitation is one of the consensual approaches which is a situation whereby a facilitator aids the parties in a conflict to reach an agreement. He further argues that facilitation is useful at the initial stage of pre-conflict.

\section{Moderation}

Moderation is also an acceptable consensual approach whereby a moderator aids the parties to reach a settlement (Burns, 2003). Moderation can be also useful in a stage of a conflict situation to resolve the conflict and evade conflict intensification (Bryman, 2004).

\section{Consultation}

Consultation is conflict resolution strategy whereby the instructor escorts the process, working on the extremely internalised views, intentions, attitudes and behaviours of conflicting parties (Best 2006). Consultation is however more suitable than moderation (Bernard 2002).

\section{Socio-therapeutic consultation}

Socio-therapeutic consultation is an unusual practise of consultation which focuses on unusual behaviour due to psychological damages (Rukuni, 2015). As a conflict resolution strategy socio therapeutic consultation is enormously essential if the parties in a conflict have already lost appearance during the course of peace building, peace-making and peacekeeping (Best,2006).

\section{Conciliation}

Conciliation is a conflict resolution strategy that can be used to resolve dispute .It is a fusion of mediation and consultation (Beranard,2002). The intermediary aids the conflicting parties to discuss their concern while addressing behaviours, internalised perceptions, intentions and attitude with the aim of deducing prejudices and hostility (Bryman, 2004). He further argues that conciliation can be used to resolve conflict situations at the initial stage.

\section{Mediation}

Miller (2003) notes that mediation involves the interference of a third party. The mediator's role is to give each party in a conflict a chance to enlighten their opinions (Miller, 2003). However, the moderator is not mandated to suggest solutions but might lead the way towards the conflicting parties. Finally, an agreement will be signed by all parties and then mediator will be responsible for sealing the agreement. As a strategy to conflict resolution, mediation can be used at any time and condition as long conflicting parties are eager to solve a dispute (Miller, 2003).

\section{Non Consensual Approaches}

Wehrmann (2008) posits that non-consensual approaches make use of third parties in decisionmaking. There is less multiplicity in non-consensual as compared to consensual approaches. Nonconsensual approaches include adjudication and arbitration (Wehrmann, 2008).

\section{Arbitration}

One of the non-consensual approaches is arbitration. Arbitration is fast and less expensive conflict resolution strategy. The arbitrator as an intermediator heeds to the opinions and to the arguments offered by all parties in a conflict. Arbitration is a flawless mixture of adjudication and mediation, presenting an opportunity of re-establishing trust and respect amongst the parties while on the other hand providing a third party judgement (Bernard,2002). Wehrmann (2008) notes that there is more flexibility in the selection of an arbitrator and chances are high of having a qualified person who is suitably trained in legal matters, accepted by both parties and who will decide fairly. Normally, a judge's choice must not be exposed.

\section{Adjudication}

Adjudication is another non-consensual approach of conflict resolution whereby a powerful authority is used to adjudicate on a dispute (Beranard 2002). The decision-maker maybe a magistrate at a court or a specialized land court or a tribunal (Wehrmann, 2008). The process follows formal procedures and rules. Both parties are often embodied by a lawyer 
who present evidence to the judge whose binding decision makes one party win and the other lose the case (Rukuni 2015). Adjudication do not re-establish the relationships between the parties. Due to its nature, adjudication must be considered as last resort.

\section{Involvement of third parties in management of disputes at global scale}

The list of land disputes and how they have been dealt with at the global level is ever-changing and broad. Conant (2014) states that, there are currently more than 150 disputes which involves territory, mostly in Africa, Asia, Pacific region, Europe and Americas. In the Sharia, mediation is regularly the endorsed method to dispute resolution. According to Saiti and Lim (2006), Solh (the doctrine of conciliation) appears in seven verses of the Qur'an. When negotiation is impossible, a third party through mediation is recommended to interfere in a land conflict willingly or through invitation (Sait and Lim, 2006). Sharia offers high precedence to indigenous resolution of disputes as contrasting to pure modern conflict resolution approaches; it lays a constructive platform for the resolution of micro-level land conflicts and is often referred to as community-based land dispute resolution (World Bank 2005). Sharing the same method is Islamic legal tradition, which does not enquire any lawyers since the litigants themselves generally beseech their own case and seeks to deal with the needs of all parties within an Islamic framework as opposed to Anglo American legal tradition (Sait/Lim 2006).

\section{Involvement of a third party in dispute resolution in Africa}

Land disputes have been dealt with in Africa are varied and wide. Moore (2010) present land dispute resolution approaches employed by the Mozambican state. The state offered those in possession of land some form of certification. Documents concerning land ownership are acceptable methods of confirmation land ownership unlike verbal evidence. Grounded on permissible methods of confirmation, a judge is obligated make a decision in favour of documentation. Moore (2010) further posits that from the perspective of small holders, illegitimate arrangement of land tenure dispute resolution, operating in aggregate, carries serious risks toward impoverishment, land degradation, rural exodus and instability. With the facilitation of programs through non-governmental organizations in Mozambique a new land regulation is an exceptionally key goal.
With aid from the non-governmental organizations, the government of Mozambique is presently seeking to revise the current land law to more effectively address problems. Namibia have reinstituted a land court of law and land policies as an effective way to deal with land disputes. Namibia's land tribunal uses a judge as an arbitrator who has a final judgement on the land disputes. The land tribunal have been functional and have resolved about 2345 land dispute cases (Moore, 2010).

In Zimbabwe there are also different strategies that have been used to manage land disputes. The government used treaties between them and the white settlers as a good method to solve land conflicts. They also used first, second and the fast track land reform programme. The government also used traditional approaches in the management of land conflicts between people within same community.

\section{Involvement of a third party at local level}

Locally the researcher seeks to assess the impact of conflict resolution strategies in the management of land disputes in Buhera District, ward 14. Buhera district ward 14 has been held under two tenure system statutory land designed for Murambinda growth point is administered by rural local authority, communal land is managed by traditional leaders grounded on customary law. Presently the land that has been apportioned for the growth point has already been used up. Efforts by the local planning authority to acquire land using local plan in the communal area of Chief Nyashanu and Chief Makumbe have since resulted in serious land disputes as the traditional leaders and community residents are not willing to give up land. Various strategies to control the situation such as the introduction of the lands tribunal, the use of local authorities in dispute resolution cases and various revised Acts of the constitution have been employed. As such this prompted the researcher to assess the impact of conflict resolution strategies in the management of land disputes in Buhera District, ward 14.

\section{Research Methodology}

The research adopted a case study research design in which both qualitative and quantitative technique was used. The case study was chosen because the researchers had insufficient funds to include all land disputes in Buhera. Results of the findings will be used to infer to all land disputes in Zimbabwe. 


\section{Data collection and sampling methods}

The study used a sample of 40 participants in Buhera. The researchers used purposive and stratified random sampling techniques. Questionnaires were used as appropriate research tools to reveal sensitive issues which respondents would otherwise feel uncomfortable to talk about in an interview. A pre-test survey was conducted in order to evaluate the validity and reliability of the questionnaire. Questions that proved to be unclear to the respondents were modified, rephrased or discarded. Key informant interviews were also used to obtain in-depth data from the selected few.

\section{Data entry and analysis}

The data collected were analyzed using descriptive statistics or frequency distribution expressed in percentages and mean item score (MIS-Using 1,2,3,4 and 5 Likert Scale). Data interpretations were based on the results that emerged from the analysis

\begin{tabular}{|c|c|c|c|c|c|c|c|c|}
\hline No & Statement & N & SA & A & N & SD & D & $\begin{array}{c}\text { MI } \\
\text { S }\end{array}$ \\
\hline 1 & Third parties are the best in resolving land disputes & 40 & 23 & 7 & 1 & 5 & 4 & 4 \\
\hline 2 & Tribunal is the best actors in resolving land disputes & 40 & 20 & 5 & 0 & 6 & 9 & 4.7 \\
\hline 3 & Non Consensual approaches are best strategies to resolve land disputes & 40 & 31 & 2 & 2 & 2 & 3 & 4.8 \\
\hline
\end{tabular}

Key: SA = Strongly Agree (5), A = Agree (4), N=Neutral (3), D = Disagree (2), SD = Strongly Disagree (1), MIS = Mean Item Score

\section{Findings and discussion}

Statement 1 which focused on third parties as best actors in resolving land disputes showed affirmative acceptance response (MIS=4). The findings are consistent with Conant (2014) who states that third parties managed to resolve more than 150 territorial disputes in Africa, Asia, Pacific region, Europe and Americas. Sharing the same method is Islamic legal tradition, which does not enquire any lawyers since the litigants themselves generally beseech their own case and seeks to deal with the needs of all parties within an Islamic framework as opposed to Anglo American legal tradition (Sait/Lim 2006). Sharing the same sentiments is Moore (2010) who argues nongovernmental organisations and Namibian tribunal successfully resolved land dispute in Mozambique and Namibia respectively. From the interviews conducted, interviewee 4 has this to say; "Traditional leaders with the help of NGOs assisted us in settling our differences pertaining to our land'. In addition, Interviewee 7 says "the interference of NGOs and our traditional leader saved us from the land conflict'. The majority of the respondents seconded the second statement (MIS=4.7). The findings are in line with sentiments of Moore (2010) who states that, Namibia reinstituted a land court of law and land policies as an effective way to deal with land disputes. Namibia's land tribunal uses a judge as an arbitrator who has a final judgement on the land disputes. The land tribunal have been functional and have resolved about 2345 land dispute cases (Moore, 2010). However the minority (MIS 0.3) revealed that arbitrators are the best actors in resolving land disputes. Sharing the same sentiments is Wehrmann (2008) who notes that there is more flexibility in the selection of an arbitrator and chances are high of having a qualified person who is suitably trained in legal matters, accepted by both parties and who will decide fairly and normally, a judge's choice must not be exposed. Non Consensual approaches were proposed to be the best way of resolving land disputes (MIS 4.8).Sharing the same view is Wehrmann (2008) who states that consensual approaches seeks to attain a solution that will be tolerable to all conflicting parties. He further states that non-consensual approaches fosters negotiations and discussions and this allows conflicting parties to understand other parties' interests, feelings, motivation and eventually their desires and fears.

\section{Conclusion}

The study showed that non-consensual strategies are effective in resolving land disputes. The mean item score for each statement has been shown on the table in which statement 3 topped (MIS $=4.8$ ) while statement 1 ranked last (MIS=4).

\section{Acknowledgements}

The researchers would like to acknowledge the patience and dedication of the participants without whom our work would have been a mammoth task to perform. 
International Journal of Trend in Scientific Research and Development (IJTSRD) ISSN: 2456-6470

\section{References}

1. Bernard R (2002) Research methods in anthropology: Qualitative and quantitative approaches. 3rd Alta Mira Press; Walnut Creek.

2. Best, S. G. (2006). Introduction to peace and conflict studies in West Africa. Spectrum Books.

3. Bryman, A. (2004) Social Research Methods (2nd edition). Oxford: Oxford University Press.

4. Burns, N. \& Grove, S. K. (2003). Understanding nursing research. 3rd ed. Philadelphia:

5. C. S. O. (2012): Zimbabwe National Report Census 2012; Government Printers, Harare.

6. Casley. D. J. and Kummar. K. (1988), The Collection Analysis And Use Of Monitoring And Evaluation Data, World Bank Publication, Washington.

7. Communal Land Act (chapter 20: 04) of 1982.

8. Cresswell J. W, Plano V. L. (2011). Designing and conducting mixed method research. 2nd Sage; Thousand Oaks.

9. Dahlitz, J. (2003). Secession and International Law: Conflict Avoidance: Regional Appraisals. New York: United Nations Publications.

10. Deininger, K. (2003) Land Policies for Growth and Poverty Reduction. A World Bank Policy Research Report. Washington.

11. Dzurgba, A. (2006). Prevention and management of conflict. Kogi, New Bodija, Ibadan: London Books Publishers.

12. FAO (2006) Land Tenure Alternative Conflict Management. FAO Land Tenure Manuals 2. Rome.

13. Fisher, S. (2000). Working with Conflict Skills and Strategies for Action. London.

14. Francis C (2012) Writing a scholarly Research Proposal: A simplified step by step Guide for young researchers. National University of Lesotho.

15. Glasl, F (1999) Konfliktmanagement. Ein Handbuch für Führungskräfte, Beraterinnen und Berater. Bern/Stuttgart.

16. Imbusch, P. (1999) Konflikttheorien. In: Imbusch, P. und R. Zoll (ed.): Friedens- und Konfliktforschung. Eine Einführung mit Quellen. (Friedens- und Konfliktforschung 1).
17. Opladen 1999, pp. 117 - 150. Irani, G., Funk, and N.: Rituals of Reconciliation: Arab Islamic Perspectives. Arab Studies Quarterly, Vol. 20.

18. Kasi P. M (2009) Research: What, Why and How? : Research Handbook. Sage Publications.

19. Kriesberg L (1997) "The Development of the Conflict Resolution Field" Peacemaking in International Conflict: Methods and Techniques, eds. I. William Zartman and J. Lewis Rasmussen, Washington DC: United States Institute of Peace Press.

20. Kuzhanga $T$.T (2013) Non-governmental organizations' role in conflict transformation: The case of Zimbabwe Since the inception of the Government of National Unity, 2009-2012. Haward College.

21. Litchman M (2009) Qualitative Research in Education. Sage publications.

22. Maoneni S (2014). Role of Traditional leaders in conflict resolution: A dissertation submitted in part fulfilment of the requirements of masters in development studies, Midlands State University.

23. Miles M. B, Huberman A. M (1994). Qualitative data analysis: An expanded sourcebook. 2nd Sage; Thousand Oaks, CA.

24. Miller, C. A. (2003). A glossary of terms and concepts in peace and conflict studies. Genera: University for Peace.

25. Patton M Q. (2002) Qualitative research and evaluation methods. 3rd Sage Publications; Thousand Oaks, CA.

26. Regional Town and Country Planning Act (chapter 29:12)

27. Rukuni T, Machingambi Z, Musingafi M C C, Kwaedza E, (2015) The Role of Traditional Leadership in Conflict Resolution and Peace Building in Zimbabwean Rural Communities:

28. The Case of Bikita District, Zimbabwe Open University.

29. Rural District Councils Act (revised 1996).

30. Sekaran, U. (2000). Research Methods for Business: A Skill Business Approach. John Wiley $\&$ Sons, New York.

31. Umstot, D. D. (1987). Understanding organizational behaviour: los. Angeles San Francisco West Publishing Co. 
32. UNEP, (2004). Dams and Development Project: Addressing Existing Dams, Issue based workshop June 14-15, United Nations Office, Nairobi.

33. Wallenstein, P., (2007). Understanding conflict resolution: war, peace and the global system. SAGE publishers. Chennai India, 47-48.

34. Wehrmann, B (2005) Land conflict in urban and peri-urban: Land Conflicts in Developing Countries. Research Reports on Urban and Regional Geography 2. Berlin.
35. Wehrmann, B., (2008). Land conflicts: A practical guide to dealing with land disputes. Handbook, Deutsche Gesellschaft für Technische Zusammenarbeit (GTZ), Eschborn, Germany.

36. World Bank (2004). Involuntary resettlement sourcebook: planning and implementation in development projects. The international bank for Reconstruction and development.

37. Washington DC ISBN 0-8213-5576-7.

38. World Bank (2005). Urban Land in Crisis: Policy Note. Washington DC

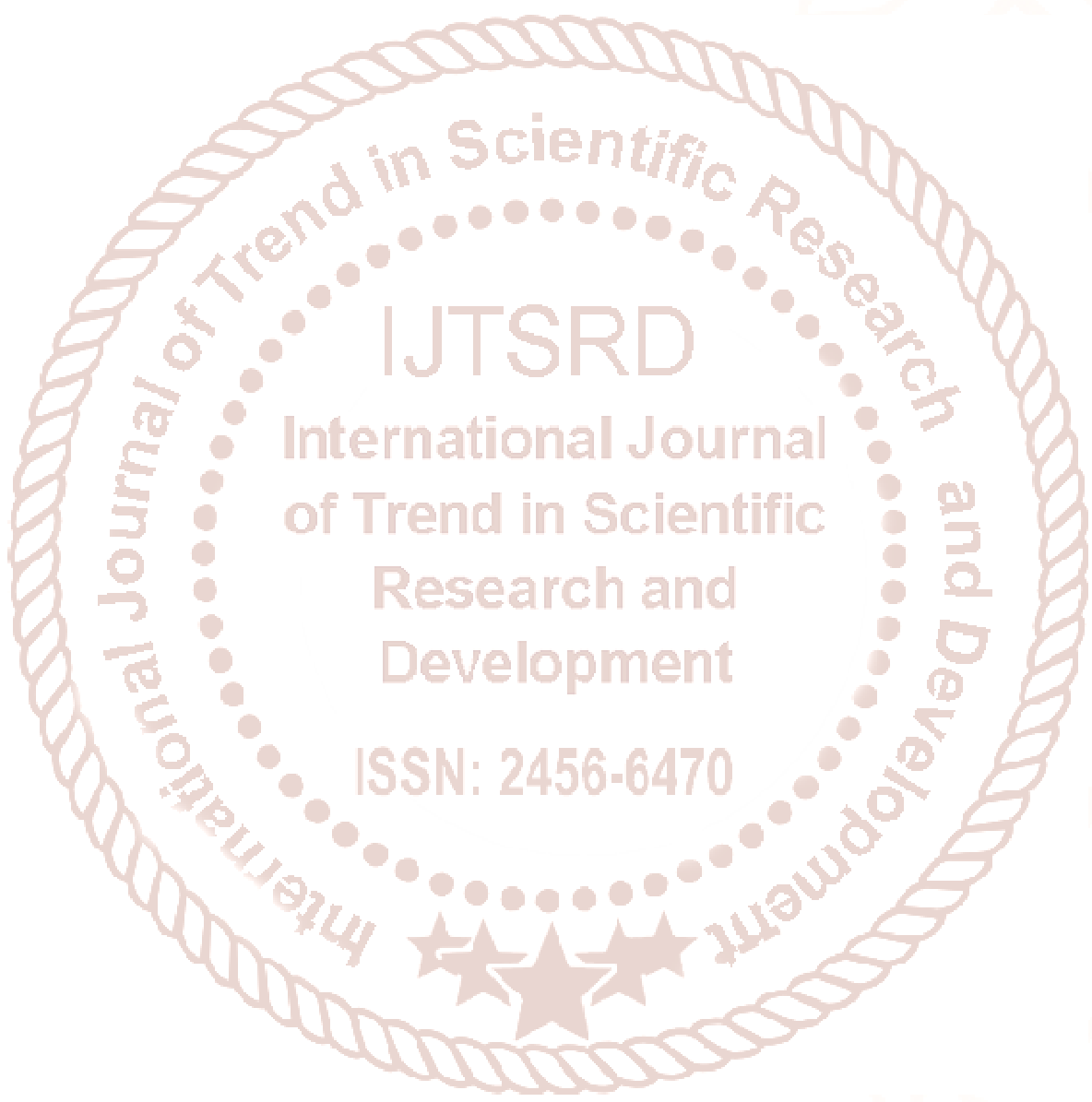

